\title{
Why is China so Attractive for FDI? The Role of Exchange Rates
}

\author{
Yuqing Xing*
}

March. 2004

\begin{abstract}
This paper argues that China's exchange policy plays a critical role in its FDI boom. Yuan's devaluation and the pegging yuan to the dollar policy not only offset the pressure of rising real wage due to sustained economic growth in the last two decades, but also improved China's competitiveness in attracting global FDI. Examining the hypothesis in the context of Japanese FDI in China's nine manufacturing sectors from 1981 to 2001, the paper finds a strong correlation between Japanese direct investment in China and the real bilateral exchange rate between yen and yuan. Empirical evidences strongly suggest that China's exchange rate policy is one of critical factors driving FDI into China.
\end{abstract}

Key Words: FDI, Exchange Rate, Manufacturing

JEL Classification: F23, F31, O53

\footnotetext{
* International Development Program, International University of Japan, Yamato-machi, Niigata-ken, 949-7277, Japan. Phone: (81)-25-779-1424, Fax: (81)-25-779-1187, email: xing@iuj.ac.jp
} 


\section{Introduction}

Relatively cheap labor in China is unanimously viewed by economists as one of prime factors attracting foreign investors. In the last two and half decades, Chinese economy grew about 9 percent annually. The cumulative economic growth should result in at least the same growth in the real wage of Chinese workers. Why is Chinese labor still cheap in the view of foreign investors? Conventional wisdom often ascribes the relative cheap labor to China's abundant labor endowment. However, it is important to realize that the labor endowment is roughly constant overtime. The cumulative devaluation of yuan since 1980 might be the answer. The devaluation not only offset the rising wage pressure due to sustained economic growth, but also strengthened China's competitiveness in attracting global FDI. For multinational enterprises, especially the ones engaging global outsourcing, the wealth and production cost effects induced by the devaluation are simply too large to ignore. It is highly likely that the surge of foreign investments inflows was substantially fueled by yuan’s devaluation.

There are numerous studies on China's FDI boom, for instance, Branstetter and Feenstra (1999) show that FDI inflows reflect political openness and state ownership in China; Cheng and Kwan (2000) find that large regional market, good infrastructure, and preferential policy are important determinants of FDI in China; Feenstra and Hanson (2003) examine the organization of export processing operations of foreign MNEs in China and test the property rights model. Lardy (1995), Henley et al (1999) and Zhang (2001) identify potential market size, low labor cost, preferential policies (e.g., tax credits), openness, geographic proximity, and political stability as primary factors attracting FDI inflows to China. 
On the other hand, the role of exchange rates in determining FDI inflows into China is largely ignored in the literature, despite of the fact that Chinese yuan have been devaluated sharply since late 1989, because of the transition of China's exchange rate regime from the dual exchange rate system to a unified single exchange rate system. Few studies investigate to what extent the drastic devaluation contributed to the surge of foreign direct investment in China.

Further, FDI in China has been export-oriented. In 2001 foreign invested firms in China exported \$133 billion, more than 50 percent of China’s total exports (China Statistics Yearbook 2002), implying that on average every \$3 FDI generates \$1 exports for China. Theoretically speaking, domestic market oriented foreign direct investment may not benefit much from the devaluation of hosting country’s currency, because a decrease in production cost resulted in by the devaluation could be offset by a corresponding decrease in sales revenues, if both being measured in foreign currency. On the other hand, it is not the case for export-oriented FDI. The segmentation between production location and product market confines the impact of the devaluation only to local production cost rather than sales prices in global market. Therefore, export-oriented FDI could benefit substantially from the currency devaluation of the hosting country.

The believers of efficient capital market hypothesis often ignore the role of exchange rates in the context. They argue that possible higher return induced by currency devaluation of hosting country will disappear as soon as domestic firms chase the higher return through borrowing foreign currency denominated loans. The efficient 
market assumption, nonetheless, does not hold in China, which still imposes tight control on international capital mobility. Its capital account has not been liberalized yet. Therefore, the potential capital return differential between domestic and foreign capitals due to currency devaluation can only be erased by continuous inflows of foreign direct investment.

Empirical investigation on exchange rate and FDI nexus is very important for the formulation of FDI and exchange rate policies. Even though China represents the largest FDI recipient among all developing countries, few systematic studies examine the role of exchange rate in the context of FDI inflows in China. This paper attempts to offset the gap in the literature and investigate to what extent China's deliberate devaluation and changing exchange rate regime contributed to its FDI boom. Specifically, this paper focuses on Japanese direct investment in China's manufacturing sectors and examines how FDI inflows from Japan were affected by the exchange rate between Japanese yen and Chinese yuan. The analysis is based on Japanese FDI in China's nine manufacturing sectors from 1981 to 2001. This is the first research that analyzes FDI in China with sectoral data rather than aggregated data. The sectoral data can provide more detail information on the characteristics of FDI than aggregated one.

There are three reasons for concentrating on direct investment by Japanese multinational enterprises (MNE). First of all, Japanese MNEs have been one of major FDI sources for China. They invested more than $\$ 2.9$ billion in 2000, making Japan the third largest single source. Secondly, Japanese FDI in China's manufacturing is mainly export oriented, following the Japanese model of FDI (Kojima, 1978). 
According to the survey by Japanese Ministry of Finance (2002), Japanese MNEs in China's manufacturing as a whole exported more than 65 percent their products to overseas market in 2001. Thus, direct investment from Japan should be relatively sensitive to variations of exchange rates. Finally, given China's existing foreign exchange rate regime, yuan is pegged to US dollar. Except a few big jumps as the consequences of yuan's devaluations, there almost exists no fluctuation in the exchange rate of the dollar to yuan. However, pegging yuan to the dollar makes yuan fluctuate against yen, as long as the later moves against the dollar. In other words, the volatility between the dollar and yen is fully transmitted to the bilateral exchange rate between yen and yuan, providing an excellent starting point to explore the issue. Given the dynamics of the bilateral exchange rate between yen and yuan, this research is not limited by a discrete exchange rate.

The paper proceeds as follows. Section II provides some stylized facts on Japanese direct investment in China and the exchange rate between yen and yuan. It emphasizes the correlation between investment inflows and the exchange rate. Section 3 reviews theories on exchange rate and FDI nexus. Section 4 discusses empirically the wealth and production cost effects of yuan's devaluation after 1981. In particular, two relative wage indexes are employed to analyze the production cost effect associate with yuna's devaluation. Section 5 presents an econometric model for testing the hypothesis that yuan’s devaluation enhanced Japanese direct investment in China through both wealth and production cost channels. The final section summarizes the major findings of the paper and policy implications.

\section{The Stylized Facts on Japanese Direct Investment in China's Manufacturing and Exchange Rates}




\section{Export Oriented Japanese FDI}

Japanese direct investment in developing countries is traditionally export oriented. By relocating production capacities of matured industries into developing countries, Japanese MNEs can combine their advantages in technology, brand name recognition, and well-established global distribution system, with low production costs of hosting countries, strengthening their global competitiveness. Extending the oligopoly power into the local market, the strategy often adopted by the US MNEs, is not the prime objective of Japanese MNEs in developing countries. Kojima (1978) refers this pattern as the Japanese model of foreign direct investment. Observing the activities of Japanese MNEs in China, it is straightforward to find that Japanese direct investment in China followed the same pattern. The export-oriented nature of Japanese MNEs in China can be confirmed by the structure of their sales destinations.

Figure 1 illustrates the destination of the sales of Japanese MNEs' subsidiaries in China's major manufacturing sectors in 2001. First of all, the Japanese subsidiaries as a whole exported more 65 percent of their products to overseas market while only less than 35 percent of their products were sold in China. Except in Chemical and Metals, the Japanese subsidiaries in all sectors exported more than 50 percent their products to the overseas market. The exports of the Japanese subsidiaries in Industrial Machinery accounted for more than 80 percent of their total sales revenues, the highest among all sectors. In Precise Instruments and Electronic Machinery, the Japanese subsidiaries made 73 percent and 70 percent of their sales revenues respectively in global market. Even in Transportation Equipment, where China is now considered as the largest unexplored market, the Japanese subsidiaries still exported 65 percent of their 
products to Japanese market and other overseas market. Japanese subsidiaries in China's textile sector exported more than 55 percent of their products. The sales structure illustrated in the figure 1 is consistent with the phenomenon, that most of “Made-in China” available in Japanese domestic market actually carry Japanese brands and many products under Japanese MNEs' brands in the global market are made in China. These facts unequivocally indicate that, Japanese domestic investment in China's manufacturing has been export-oriented. Using China as a production base serving Japanese domestic market as well as the global market is the primary objective of Japanese FDI in China.

$$
<<\text { Figure } 1>>
$$

\section{The Correlation between Japanese FDI and the Real Exchange Rate}

The sharp appreciation of yen as the result of the Plaza Accord of 1985 has been recognized as one of major factors pushing Japan to be the largest capital exporting country, through either green field FDI or acquisition activities (Won and Yamamura, 1996). Examining Japanese FDI inflows in China closely, along with the fluctuation of the bilateral exchange rate between yen and yuan, it is straightforward to observe a strong correlation between the two variables. Figure 2 plots trends of annual Japanese direct investment inflows in China and the real bilateral exchange rate between yen to yuan during the period 1981 to 2001. The exchange rate is defined as the value of yen in terms of yuan. As indicated in figure 2, the appreciation of yen was always followed by an increase in Japanese FDI inflows in China, while the depreciation yen was associated with a decrease of FDI. As yen experienced sharp appreciation in late 1980s and early 1990s, the influx of Japanese direct investment in China also surged abruptly. From 1989 to 1995, yen continued to appreciate against yuan, due to the deliberate devaluation of yuan and yen's appreciation against the dollar. In the same 
period, Japanese FDI in China’s manufacturing jumped more than 12 times, rising to 336.8 billion yen in 1995 from annual inflows 27.6 billion yen in $1989^{1}$. The rising trend of Japanese direct investment in China reversed in 1996. The declination of Japanese FDI in the following years consistently followed the path of weakened yen. It is worth to notice that, contrary to conventional wisdom which claims that the decline of Japanese FDI in China was due to the Asian financial crisis, Japanese FDI actually started to decline in 1996, one and half years earlier than the Asian financial crisis! The sharp decline in FDI was mainly attributed to the weakened yen. As yen appreciated in 1998, Japanese FDI in China started to rise again. The pattern revealed by the figure implies that Japanese multinational enterprises strategically took the advantage of exchange rate fluctuation, making more direct investment as yen appreciated and lowering the pace of their investment while yen depreciated. All these suggest that there must exist a non-coincidental relationship between the bilateral exchange rate of yen to yuan and Japanese direct investment in China. The exchange rate might be one of major factors determining Japanese FDI inflows in China

$$
<<\text { Figure } 2>>
$$

\section{Yuan's Devaluation Since 1989}

Chinese yuan has been on a track of devaluation since 1980. If yuan's devaluations before 1989 simply corrected yuan's over-valuation under the central planning economy, the devaluations after that might make yuan undervalued, enhancing China's global competitiveness in attracting FDI. The Chinese government devaluated yuan a few times from 1989 to 1994 (Table 2). As a result, average nominal exchange rate of yuan to the dollar rose sharply from 3.76 yuan/dollar in

\footnotetext{
${ }^{1}$ The numbers do not include the reinvestment of Japanese MNEs in China.
} 
November 1989 to 8.62 yuan/dollar in January 1994, representing more than 56 percent devaluation of yuan. Two factors are often cited as the reason behind the sharp devaluation. One is the domestic inflation cumulated in the period ( $\mathrm{Xu}, 2001)$. The other is merging official exchange rate with the market rate (World Bank, 1994). However, even measured in real term, the value of yuan still shrank 35 percent against the dollar ${ }^{2}$. In the same period, yuan devalued even more in terms of yen than in terms of the dollar. The nominal exchange rate between yen and yuan dropped to 12.77 yen/yuan from 38.58 yen/yuan, a nearly 67 percent depreciation. Pegging yuan to the dollar led to the relative high devaluation of yuan against yen, because yen appreciated against the dollar substantially during the period. From January 1994 to April 1995, under the so-called "Managed Floating System," yuan actually appreciated about 7.5 percent against the dollar. However, the sharp appreciation of yen against dollar in the same period resulted in yuan's further depreciation against yen, the nominal exchange rate between yuan and yen falling to 9.9 yen/yuan, a further 23 percent depreciation from the level in January 1994. Excluding inflation, Japanese yen appreciated against Chinese yuan more than 53 percent cumulatively from 1989 to 1995 . It is subject to debate whether yuan's devaluation was intended to enhance China's competitiveness in attracting FDI. The exchange rate policy, nevertheless, unambiguously strengthened China's competitiveness as a global production base for MNEs .

$$
<<\text { Table } 1>>
$$

\section{Exchange Rates and FDI: A Literature Review}

The mechanism that exchange rates affect FDI flows has been modeled in a few theoretical studies (e.g., Kohlhagen, 1977; Cushman, 1985; Froot and Stein, 1991).

\footnotetext{
${ }^{2}$ Real exchange rate of Chinese Yuan to the US dollar in 1989 and 1994 are 140.85 and 91.51 respectively (IMF Financial Statistics). Higher value indicates a real appreciation of Chinese Yuan.
} 
Most of these studies reach a conclusion that a devaluation in the value of FDI hosting country's currency stimulates inflows of foreign direct investment and conversely an appreciation leads to a reduction in FDI inflows. Fundamentally, there are two channels through which exchange rates impact FDI: wealth effect channel and relative production cost channel. A devaluation in the currency of FDI receiving country induces a reduction in local production cost in term of foreign currency, raising profit of export-oriented foreign investors accordingly. Higher return naturally attracts more FDI inflows. The wealth effect-relative wealth of foreign investors to domestic investors is also raised after the devaluation. From the point of the views of foreign investors having capitals measured in foreign currency, all production inputs such as labor, land, machines, and assets in FDI hosting country become cheaper after the devaluation, encouraging them to acquire more domestic assets.

For multinational enterprises engaging in greenfield foreign direct investment, the most significant benefit of a devaluation in hosting country's currency is relatively low production costs. The depreciation leads to a reduction in the costs of inputs that purchased locally such as labor, land, and intermediate inputs. It is particular important for export-oriented FDI since the segmentation between production location and products market can prevent sales price from being impacted by the devaluation. Kohlhagen (1977) used a static model analyzing the effect of a devaluation on the location decisions of multinational enterprises. He concluded that multinational enterprises tend to increase their production capacity in foreign country for serving domestic market, if foreign currency is devaluated against domestic currency. Cushman (1985) considered a two periods dynamic model in which the firm 
maximizes future real profits measured in the domestic currency. He considered both exchange rates and the expected volatility of exchange rates, and reached a conclusion that, the direct effect of risk-adjusted expected real appreciation in the value of home country's currency would lower foreign investors production costs, thus stimulating inflows of foreign direct investment. As an extension of Cushman, Benassy-Quere (2001) examined the trade-off between exchange rate depreciation and its volatility in terms of their effects on FDI. He argued that the negative impact of excessive volatility on FDI might defuse apparent attractiveness induced by the currency depreciation.

The wealth channel of exchange rates' effect on FDI is modeled by Froot and Stein (1991). Assuming imperfect information on the return of firm-specific assets, they argued that the appreciation of foreign currency actually increases relative wealth of foreign investors and thus lowers the price of domestic assets in term of foreign currency. Therefore, the wealth effect would raise the leverage of foreign firms on acquiring domestic assets and enhance FDI inflows. Blonigen (1997) provided an alternative view on the wealth effect o the currency devaluation in the FDI hosting countries. He argued that the appreciation of foreign currency enables foreign investors to offer higher prices for domestic firm-specific assets than domestic bidders, because foreign investors can access foreign market, which is segmented from domestic market and cannot be accessed by domestic bidders. Blonigen tested his hypothesis on Japanese acquisition activities in the US and found that the appreciation of Japanese yen resulted in a significant increase in Japanese acquisition activities in the US. 
A few empirical studies, including Klein and Rosenger (1994), Dewenter (1995), Goldberg and Klein(1997), and Bayoumi and Lipworth (1998), provide evidences supporting the theoretical arguments on the relation between exchange rates and FDI. Most of empirical researches on the context are based on the experienced of industrialized countries, in particular, the United States. Goldberg and Klein (1997) offered a comprehensive study concentrating on the role of real exchange rates in determining FDI flows from Japan and the United States to Southeast Asia and Latin America. Their empirical results indicate that the appreciation of yen and the dollar did boost direct investment from Japan and US to these areas.

\section{The Wealth and Production Cost Effects of Yuan's Devaluation}

Real exchange rate measures the relative price level of two countries. The change of real exchange rate reflects the variation of purchasing power of one country's currency in term of goods and services of the other country. Examining the dynamics of the real exchange rate between yen and yuan could reveal the wealth effect due to yuan’s devaluation. From 1981 to 1995, Japanese yen appreciated cumulatively 86 percent against yuan in real term (Figure 1). It implies that yen's purchasing power measured by China's goods and services rose 86 percent consequently. Most of the appreciation, about 74 percentage point, occurred during the period 1989 to 1995, due to yuan's sharp devaluation as well as yen's appreciation against the dollar. Unequivocally, the cumulative wealth effect is highly significant and could not be ignored by any Japanese MNEs. The substantial wealth effect definitely raised Japanese MNEs' leverages for acquiring assets in China, promoting Japanese FDI into China. 
For illustrating the production cost effect of yuan's devaluation, we introduce two relative wages of Japanese workers to Chinese workers. One is exchange-rate-free relative wage (EFW). The other is exchange-rate-adjusted relative wage (EAW). EFW is defined as the ratio of Japanese real wage to Chinese real wage. Both the real wages are measured in local currency respectively. Thus, EFW is not affected by the fluctuation of yuan's devaluations. The index of EFW reflects the change of Japanese real wage relative to Chinese real wage without the distortion of exchange rates.

The second relative wage EAW is defined as the ratio of nominal Japanese wage to nominal Chinese wage that is converted into yen based on the yearly average nominal exchange rate. Hence, the change of EAW depends on not only the relative change of the wages, but also exchange rate variations. The labor cost measured by EAW is actually the relative labor cost bore by the Japanese MNEs having operations in the two countries. In terms of labor cost, only EAW matters when Japanese MNEs consider whether to invest in China or not. Comparing the indexes of EFW and EAW would reveal to what extent the exchange rate impacted the relative labor cost between the two countries.

Figure 3 shows the indexes of EFW and EAW from 1981 to 2001. 1981 is the base year for both indexes. Clearly, the index of EFW from 1981 to 2001 moved along a downward sloping curve. It decreased to 30 in 2001, less than one third of its level in 1981, indicating that Japanese workers became relatively much cheaper than before. Alternatively speaking, Chinese workers' relative wage rose more than three times and Chinese workers become relatively more expensive. Given that Chinese economy grew much faster than Japanese economy in the last two decades, it is not 
surprised that Chinese workers would be relatively more expensive than before if the exchange rate was fixed.

The index of EAW, however, presents of a distinctive scenario. In contrast to the downward trend of EFW, the index of EAW rose continuously from 1981 to 1995 and increased to 230 in 1995, implying that Japanese workers relative wage, adjusted by the exchange rate, grew more than 2.3 times compared with that in 1981 . In other words, Chinese workers became much cheaper while Japanese workers more expensive. Considering that EFW is exchange rate adjusted relative wage and Chinese workers wage actually grew much faster than that of Japanese, yuan's devaluations and pegging yuan to the dollar policy are the sole factor that drove up the relative wage. It is worth to mention that, even though yen depreciated substantially against yuan after 1995, the exchange-rate-adjusted wage in 2001 just fell back to the level in 1981. In other words, after two decade long rapid economic growth, Chinese labor is still as cheap as it was, if the labor cost is measured in Japanese yen. Hence, yuan's devaluation and the pegging yuan to the dollar policy, not only reduce China's labor cost but also offset the rising wage pressure due to the sustained economic growth in the last two decades.

$$
<<\text { Figure } 3>>
$$

The wealth and production cost effects due to yuan's devaluation unambiguously strengthened China's position in competing FDI with other developing countries. Before 1990 ASEAN-4 had been the major host of Japanese FDI. Japanese FDI in China's manufacturing accounted for merely 5\% of total Japanese FDI in Asian's manufacturing industry in 1990 (Figure 4). However, it rose sharply after yuan’s devaluation. In 1995, almost half of Japanese FDI in Asian countries’ manufacturing, 
about 47 percent, ended in China. China has replaced the ASEAN-4 as the number one recipient of Japanese FDI in Asian and pacific region. Before the Asian financial crisis, Indonesia, Malaysia, Thailand, and Philippines all pegged their currencies to the dollar. Yuan's sharp devaluation naturally led to the appreciation of these countries’ currencies to yuan. Consequently, Chinese labor became relatively cheaper than the labor of ASEAN-4, triggering the shift of Japanese FDI from ASEAN-4 to China. The economic chaos in ASEAN-4 due to the Asian financial crisis cannot explain the shift from ASEAN-4 to China, as indicated by Figure 4, China emerged as a major host of Japanese FDI long before the Asian finical crisis.

$$
<<\text { Figure } 4>>
$$

\section{The Econometric Analysis}

In interpreting exchange rate and FDI nexus, both the production cost argument and the imperfect capital market theory predict that a devaluation in the currency of FDI hosting country will induce an increase in FDI inflows while an appreciation discourage the inflows of FDI. For testing the validity of the hypothesis in the context of Japanese FDI inflows into China, this paper basically follows empirical framework used in the current literature (e.g. Klein \& Rosengren, 1994) with some modifications by including additional variables the sectoral growth rate and openness index, because both of them change over time. Specifically, the following model specification is employed:

$\log \left(F D I_{i t} / G D P_{t}\right)=\alpha+\beta_{1} \log \left(e p_{j} / p_{c}\right)_{t}+\beta_{2}\left(e w_{j} / w_{c}\right)_{t}+\beta_{3} t+\beta_{4} \log \left(g_{i t}\right)+\beta_{5} \log \left(\right.$ Open $\left._{t}\right)+\varepsilon_{t}$

$G D P_{t}$ : China' real GDP, 
$F D I_{i t}$ : Japanese FDI in sector i,

$t$ : time trend,

$g_{i t}$ :the real growth rate of sector $\mathrm{i}$ in China.

open $_{t}$ : the openness index for China,

$e:$ nominal exchange rate (yuan/yen),

$p_{j}:$ the price level in Japan,

$p_{c}$ :the price level in China,

$w_{j}$ : nominal wage in Japan,

$w_{c}$ : nominal wage in China.

According to the model specification, dependent variable is defined as the ratio of annual inflows in a manufacturing sector to China's real GDP in the same period. With respect to FDI theory, rising size of an economy generally raises its gravity to foreign direct investment, assuming other factors constant. It is referred as market size effect. Adjusting FDI flows by real GDP eliminates the influence of rising GDP on the scale of FDI inflows. Thus, the specification actually models the variation of FDI inflows that is determined by other factors along the time horizon.

The first independent variable $\left(e p_{j} / p_{c}\right)_{t}$, is the bilateral real exchange rate between yen and yuan. It measures relative price level between China and Japan, where $e$ is nominal exchange rate (yuan/yen), the value of yen in terms of yuan. Higher $e$ indicates an appreciation in yen. Accordingly, higher $\left(e p_{j} / p_{c}\right)_{t}$ implies a real appreciation in yen. If as expected, yen appreciation leads to an increase in direct investment inflows from Japan, the coefficient of the real exchange rate should be 
positive and significant. $\left(e p_{j} / p_{c}\right)_{t}$ functions as a proxy of the wealth effect associated with yuan's devaluation in the model.

The second independent variable $\log \left(e w_{j} / w_{c}\right)_{t}$ is exchange rate adjusted relative wage. It measures the production cost effect of the exchange rate on Japanese FDI in China, specifically, the labor cost effect. The higher the relative wage means that Japanese workers are more expensive. If the production cost effect contributed to the inflows of Japanese FDI significantly, more Japanese FDI should be expected as the relative wage rises. Thus, the coefficient of the relative wage is expected to be positive. The other independent variables include time trend, sectoral growth rate, and openness. The time trend may catch the momentum of FDI inflows. Real growth rate in a manufacturing sector generally represents the average rate of return to capital in the sector. Given other factors constant, sectors with higher growth would attract relatively more FDI inflows. Hence, the coefficient of the sectoral growth rate is expected to be positive. The openness index is measured as the ratio of total trade volume to GDP. The coefficient of the openness is expected to be positive too, because more FDI inflows are expected as an economy is integrated more with the global economy.

According to the sectoral classification by Japanese Ministry of Finance on FDI, manufacturing sector consists of nine sub-sectors: Food, Lumb \& Pulp, Chemical, Metal, Textile, Electrical, Machinery, Transportation Equipment, and Others. To estimate equation (1), Japanese direct investment inflows to China in these nine sectors are used. The data covers the period of 1981 to 2001. However, not all sectors in China started to receive Japanese FDI in 1981. Time ranges of FDI data 
vary across sectors. The panel data consist of total 163 observations. The FDI data complied by Japanese Ministry of Finance include only capital flows that actually crossing the border between China and Japan. Annual reinvestments by Japanese affiliates already operating in China are not included. Real exchange rate $\left(e p_{j} / p_{c}\right)_{t}$ is calculated by using two reference real exchange rates: the real exchange rate between yuan and the dollar and that between the dollar and yen as follow:

$$
\left(e p_{j} / p_{c}\right)=\frac{\left(e_{\$ / \text { yen }} p_{j} / P_{u s}\right)}{\left(e_{\$ / \text { yuan }} p_{c} / P_{u s}\right)}
$$

The denominator of the right side in equation (2) is the real exchange rate between yuan and the dollar, the numerator the real exchange rate between yen and the dollar. Both reference real exchange rates are retrieved from International Financial Statistics.

We first estimated model (1) with all independent variables. Since the panel data is used, both pooled regression and fixed effects model are estimated. Table 2 summarizes the major results. In the pooled regression, the coefficient of $\log \left(e p_{j} / p_{c}\right)_{t}$ is 1.471 and statistically significant at 5\%. In the fixed effect model, the coefficient of $\log \left(e p_{j} / p_{c}\right)_{t}$ is 1.533 and statistically significant at $1 \%$. The empirical results confirm the predication that a depreciation of Chinese yuan (an appreciation of Japanese yen) leads to an increase of Japanese direct investment in China. Alternatively, whenever Japanese yen appreciates, rising Japanese direct investment inflows into China will be expected. There would be less Japanese direct investment flowing into China if yen become weaker. Since $\log \left(e p_{j} / p_{c}\right)_{t}$ measures the relative purchasing power of Japanese yen and is a proxy of the wealth effect, the empirical 
results suggest that the wealth effect due to yuan's devaluation drove up the inflows of Japanese direct investment in China. The rising purchasing power of Japanese yen accelerated the expansion of Japanese MNEs in China and encouraged further capital inflows. As the relative wealth of Japanese investor decreases because of yen's depreciation against yuan, Japanese firms would reduce their investment substantially. Note that both the dependent variable and the real exchange rate are in logarithm. The coefficient of the real exchange rate measures the elasticity of Japanese FDI inflows to the real exchange rate. Specifically, the estimate of the fixed effect model shows that, a one percent real appreciation of yen against yuan will give a rise to an expected 1.456 percent increase in Japanese FDI in China's manufacturing. In the fixed effects model, the elasticity of FDI to the real exchange rate is higher than that in the pool regression model. The F-test for testing the significance of group effects (Green, 2003) indicates that the fixed effect model fits the data better than the pooled regression model.

The estimated coefficients of the relative wage $\log \left(e w_{j} / w_{c}\right)_{t}$ are insignificant in both the pooled regression and the fixed factor model. However, we do not conclude that the insignificance of $\log \left(e w_{j} / w_{c}\right)_{t}$ means the production cost effect failed to stimulate the inflows of Japanese FDI. Basically, the insignificance is caused by the strong correlation between the real exchange rate and the relative wage, because both of the independent variables are a function of the exchange rate $e$. In the case that both independent variables are included in the model, the relative strong explanatory power of the real exchange rate overshadows the contribution of the relative wage, leading to the insignificance of the later. Removing one of them would correct the problem. Thus, additional models that include only one of the two exchange rate 
related independent variables are estimated. Similarly, in each case, both pooled regression and fixed effects models are estimated.

The estimations of these models are also reported in table 2. After eliminating $\log \left(e p_{j} / p_{c}\right)_{t}$, the estimated coefficient of the relative wage $\log \left(e w_{j} / w_{c}\right)_{t}$ is 1.442 and statistically significant at $1 \%$ in the pooled regression, 1.511 in the fixed effects model which is also highly significant at $1 \%$, implying that the production cost effect induced by yuan's depreciation enhanced significantly the inflows of Japanese FDI. The decreasing labor cost in the period due to yuan's devaluation made China attractive to Japanese investors, facilitating the influx of Japanese FDI substantially. The relatively abundant labor endowment in China is one of the reasons for the relative low labor cost. However, the labor endowment is a given parameter. It could not lead the declination in the labor cost given that Chinese economy grew rapidly. Therefore, the declining labor cost is independent of the labor endowment. Yuan's devaluations since 1981 are the sole factor causing the reduction in the labor cost, which in turn attracted FDI. The significance of relative wage $\log \left(e w_{j} / w_{c}\right)$ shows the exchange rate regime played a critical role in China's FDI boom. It also indicates the importance of the exchange rate in maintaining low labor cost that is essential for China to attract FDI and be a global factory. The estimated coefficient of the relative wage $\log \left(e w_{j} / w_{c}\right)$ measures the elasticity of FDI to the relative wage and greatly exceeds one. Hence, Japanese FDI is highly elastic to the change of the relative wage. The significance of $\log \left(e p_{j} / p_{c}\right)_{t}$ remains unchanged after excluding $\log \left(e w_{j} / w_{c}\right)$. The estimated coefficient of $\log \left(e p_{j} / p_{c}\right)_{t}$ is 1.357 in the pool regression and 1.458 in the fixed effects model and both are highly significant at 1 percent. These results are 
consistent with the previous one and supporting the hypothesis that the wealth effect induced by Yuan's devaluation facilitated the inflows of Japanese FDI in China substantially.

The estimated coefficient of sectoral growth rate is also positive and statistically significant at 5 percent in all fixed effects models, indicating that the real growth of each sector also contributed to the surge of Japanese FDI in China in the last two decades. The coefficient of the openness, however, is insignificant in all the cases. The insignificance may be ascribed to the definition of the dependent variable, in which the effect of China's GDP on FDI is filtered out. As China's openness has almost a linear relationship with China's GDP, it is highly likely that the impact of the openness is also filtered out, resulting the insignificance of the openness index in the model.

Considering that the empirical analysis covers Japanese FDI in all China's manufacturing sectors and the period from 1981 to 2001, we conclude that the bilateral exchange rate between yen and yuan is one of key factors determining Japanese FDI in China. The wealth effect together with production cost effect induced by yuan's devaluation's in the last two decades, significantly enhanced the China's competitiveness in attracting global FDI and stimulated the increase of FDI inflows in China. After two and half decade high growth, the real wage of Chinese workers measured in yuan has risen a few times. Measured in the dollar, or yen, however, the increase of the real wage is negligible. A series of yuan's devaluation not only offset the increase in the real wage, but also maintain China's competitiveness in labor intensive industry, which in turn attract huge inflow of 
export-oriented FDI that always chasing for cheap production base globally. Whether China's strategically devalued yuan for the purpose of attracting FDI remains a question. The empirical results unequivocally suggest that yuan's devaluation facilitated the inflows of FDI substantially.

It is biased and inappropriate to solely ascribe China's success in attracting FDI to the exchange rate policy. As the paper focuses on the variations of Japanese FDI in China over more than twenty years horizon, the structure variables which are constant in general could not explain the dynamics of Japanese direct investment in China, especially the variations. The time-variant exchange rate could be the most appropriate exogenous variable for interpreting the change of the FDI inflows. All empirical evidences presented in the paper are consistent with the hypothesis and unequivocally demonstrate that, through the wealth and production cost channels, China's exchange rate policy enhanced the inflows of FDI in China.

The specification in equation (1) does not include many structure variables such as market size, tariffs, tax rates, etc. There are a few rationales for not considering these variables in this paper. With regards to the definition of the dependent variable (FDI/GDP), the impact of market size in FDI inflows has been filtered out from the dependent variable. The FDI inflows considered in the model should be independent of the market size. Tax heaven hypothesis for FDI determination is generally tested with cross-country data, creating variation for relative tax rates among FDI hosting countries. The FDI flows in the context, however, are the one from a single source country to another single host country. Therefore, the relative tax rate between the two should be time-invariant and has no impact on the variation of the inflows. 
Jumping over tariff-wall hypothesis on FDI motivation applies only to domestic market oriented FDI. As argued before, majority FDI in China, particularly Japanese direct investment, are export-oriented. Tariffs should be irrelevant.

\section{Concluding Remarks}

There is a plethora of literature on China's FDI boom. However, the role of China's exchange rate policy has been largely ignored, even though exchange rates are critical in the decision of MNEs' FDI activities (see Feenstra, 1999, for an excellent survey). This paper basically fills the gap, investigating the exchange rate and FDI nexus in the context of Japanese FDI in China. Using a panel data covering Japanese direct investment in China’s nine major manufacturing sectors from 1981 to 2001, the paper found that yuan's cumulative devaluation created substantial wealth and production effects, leading to the surge of Japanese direct investment in China. The real exchange rate is one of significant determinants of Japanese FDI in China. Specifically, the appreciation of yen stimulated substantially the inflows of Japanese direct investment while the depreciation of yen leading to a substantial decrease of Japanese FDI. To a large extent, the rise and fall of Japanese direct investment in China over the period is attributed to the fluctuations of the bilateral real exchange rate. It is the weaken yen that led to the declination of Japanese FDI in China after 1995 rather than the Asian financial crisis.

It is biased if we solely ascribed China's success in attracting FDI to its exchange rate policy. As argued by many scholars, structure variables such as GDP growth, preferential policies, etc. also drove the inflow of FDI into China. However, it is imperative to realize the critical role of exchange rates in the decision process of 
MNEs. As China competes with other developing countries for global FDI, the devaluation of yuan and pegging to the dollar policy unambiguously enhanced China's comparative advantage in production costs and made China an ideal place for global outsourcing of MNEs. For instant, rising labor cost is inevitable as an economy continues to grow rapidly. On the other hand, if we measure the real wage of Chinese workers in foreign currency such as yen, the real wage of today is almost same as it was twenty years ago. Yuan's cumulative devaluation as well as the pegging to the dollar actually offset the increase in the real wage accumulated in the last two decades and maintain China's competitiveness in labor intensive industry. It is debatable whether the Chinese government devaluated yuan for attracting FDI. The fact is that the wealth and production cost effects associated with yuan's devaluation facilitated the inflow of FDI, particularly the export-oriented FDI, which in turn contributed to the rapid growth of China's exports.

Whether Chinese yuan should appreciate or not has been debated among scholars and policy makers recently. Based on the analysis of this paper, the appreciation of yuan will undermine China's competitiveness in attracting export-oriented FDI. The slow down of export-oriented FDI will in turn weaken China's export growth, which has been one of growth engines for Chinese economy. Considering the unemployment pressure and weak domestic demand faced by Chinese economy today, it is too early to let yuan appreciate. 


\section{References}

Bayoumi, T. and G. Lipworth (1998), “Japanese Foreign Direct Investment and Regional Trade,” Journal of Asian Economics, 9(4), pp581-607.

Benassy-Quere, A, L. Fontagne, and A. Lahreche-Revil (2001), "Exchangre Rate Stretigies in the Competition for Attracting Foreign Direct Investment," Journal of the Japanese and international Economics, 15, pp178-198

Blonigen, B. A. (1997), "Firm-Specific Assets and the Link Between Exchange Rates and Foreign Direct investment," American Economic Review, 87(3), pp447-465.

Branstetter, Lee and Robert Feenstra, Trade and Foreign Direct Investment in China:

A Political Economy Approach, 1999, NBER working paper.

Chen, C., (1996), "Regional Determinants of Foreign Investment in Mainland China, “ Journal of Economic Studies, 23, pp18-30.

Cheng, L. K, and Kwan, Y. K. (2000), What Are the Determinants of the Location of Foreign Direct Investment? The Chinese Experience, Journal-of-InternationalEconomics, 51(2): 379-400.

China Statistics Yearbook 2001, China Statistics Press, Beijng.

Cushman, D. O. (1985), "Real Exchange Rate Risk, Expectation, and the Level of Direct Investment,” Review of Economics and Statistics, 32, pp297-308.

Dewenter, K. L. (1995), “Do Exchange Rate Changes Drive Foreign Direct Investment?” Journal of Business, 68(3), pp405-433.

Feenstra, R. and G. Hanson (2003), "Ownership and Control in Outsourcing to China: Estimating the Property-Rights Theory of the Firm,” NBER Working paper.

Froot, K. A. and J. C. Stein (1991), "Exchange Rates and Foreign Direct Investment: an Imperfect Capital Market Approach,” Quarterly Journal of Economics,

Goldberg, L.S. and M.W. Klein (1997), "Foreign Direct Investment, Trade and Real Exchange Rate Linkages in Southeast Asia and Latin America," NBER working paper 6344.

Green, W. H. (2003), Econometric Analysis, Prentice Hall, Upper Saddle River, New Jersey.

Kohlhagen, S. W. (1977), "Exchange Rate Changes, Profitability, and Direct foreign Investment,” Southern Economic Journal, 68, pp43-52. 
Klein, M. W. and E. Rosengren (1994), “The real Exchange Rate and Foreign Direct Investment in the United States: Relative Wealth vs. Relative Wage Effects,” Journal of International Economics, 36, pp373-389.

Kojima, K. (1978), Direct Foreign Investment: A Japanese Model of Multinational Business Operations, Croom Helm, London.

Henley, J., C. Kirkpatrick, and G. Wilde (1999), "Foreign Direct Investment in China: Recent Trend and Current Policy Issues,” World Economy, 22(2), pp23-43.

Lardy, N. (1995), “The Role of Foreign Trade and Investment in China's Economic Transformation,” China Quarterly, 144, pp1065-82

METI (2002), Quarterly Survey of Business Activities, various issues, Tokyo. UNCTAD (2002), World Investment Report 2002, UNCTAD, Geneva.

Wong K. and K. Yamamura (1996), “Japan’s Direct Investment in the United States: Cause, Patterns, and Issues,” in The Effect of Japanese Investment on the World Economy, L. Hollerman and R. H. Myers (ed.), Hoover Institute Press, Stanford University, Stanford, CA.

World Bank (1994), China Foreign Trade Reform, World Bank, Washington, D.C.. Xu, Y(2001), “China’s Exchange Rate Policy,” China Economic Review, 11, pp262277.

Zhang, K.H. (2001), "What Attracts Foreign Multinational Corporations to China?” Contemporary Economic Policy, 19(3), pp336-346. 
Table 1 Yuan's Devaluation against Dollar and Yen: Nov. 1989 to April. 1995

\begin{tabular}{|l|c|c|c|c|}
\hline & $\begin{array}{c}\text { Official } \\
\text { Exchange Rate } \\
\text { (Yuan/Dollar) }\end{array}$ & $\begin{array}{c}\text { Depreciation* } \\
\text { against Dollar } \\
(\%)\end{array}$ & $\begin{array}{c}\text { Official } \\
\text { Exchange Rate } \\
\text { (Yen/Yuan) }\end{array}$ & $\begin{array}{c}\text { Depreciation* } \\
\text { against Yen } \\
(\%)\end{array}$ \\
\hline Nov. 1989 & 3.72 & & 38.59 & \\
\hline Dec. 1989 & 4.72 & 21.2 & 30.44 & 21.1 \\
\hline Nov. 1990 & 5.22 & 9.6 & 24.75 & 18.7 \\
\hline March 1993 & 5.73 & 8.9 & 20.36 & 17.7 \\
\hline Jan. 1994 & 8.72 & 34.1 & 12.77 & 37.3 \\
\hline April 1995 & 8.44 & -7.5 & 9.91 & 22.4 \\
\hline
\end{tabular}

*The percentage change of Yuan's value in terms of Dollar/Yen from previous period.

Source: PACIFIC Exchange Rate Service, World Bank (1994)

Table 2 The Impact of Real Exchange Rates on Japanese FDI in China

\begin{tabular}{|c|c|c|c|c|c|c|}
\hline Independent & \multicolumn{3}{|c|}{ Pooled Regressions } & \multicolumn{3}{|c|}{ Fixed Effects } \\
\hline Const. & $\begin{array}{l}-11.717^{* *} \\
(2.800)\end{array}$ & $\begin{array}{l}-11.933^{* *} \\
(2.395)\end{array}$ & $\begin{array}{l}-14.520 \\
(2.265)\end{array}$ & & & \\
\hline $\log \left(e p_{j} / p_{c}\right)_{t}$ & $\begin{array}{l}1.471^{* *} \\
(0.856) \\
\end{array}$ & $\begin{array}{l}1.357 * * * \\
(0.428)\end{array}$ & & $\begin{array}{l}1.533^{* * *} \\
(0.624) \\
\end{array}$ & $\begin{array}{l}1.458^{* * *} \\
(0.326) \\
\end{array}$ & \\
\hline $\log \left(e w_{j} / w_{c}\right)_{t}$ & $\begin{array}{l}-0.167 \\
(0.878)\end{array}$ & & $\begin{array}{l}1.442 * * * \\
(0.547)\end{array}$ & $\begin{array}{l}-0.108 \\
(0.775)\end{array}$ & & $\begin{array}{l}\text { 1.511*** } \\
(0.413)\end{array}$ \\
\hline $\log \left(g_{i t}\right)$ & $\begin{array}{l}0.480 \\
(0.154)\end{array}$ & $\begin{array}{l}0.512^{* *} \\
(0.260)\end{array}$ & $\begin{array}{l}0.783 * * * \\
(0.287)\end{array}$ & $\begin{array}{l}0.444^{* *} \\
(0.247)\end{array}$ & $\begin{array}{l}0.465 * * * \\
(0.198)\end{array}$ & $\begin{array}{l}0.742^{* * *} \\
(0.218)\end{array}$ \\
\hline $\log \left(\right.$ open $\left._{t}\right)$ & $\begin{array}{l}0.987 \\
(1.345)\end{array}$ & $\begin{array}{l}0.869 \\
(1.104)\end{array}$ & $\begin{array}{l}0.522 \\
(1.326)\end{array}$ & $\begin{array}{l}1.100 \\
(0.976)\end{array}$ & $\begin{array}{l}1.029 \\
(0.833)\end{array}$ & $\begin{array}{l}0.796 \\
(0.983)\end{array}$ \\
\hline$t$ & $\begin{array}{l}-0.017 \\
(0.880)\end{array}$ & $\begin{array}{l}-0.001 \\
(0.045)\end{array}$ & $\begin{array}{l}0.130 * \\
(0.075)\end{array}$ & $\begin{array}{l}-0.019 \\
(0.080)\end{array}$ & $\begin{array}{l}-0.008 \\
(0.034)\end{array}$ & $\begin{array}{l}0.125 * * * \\
(0.056)\end{array}$ \\
\hline Adj. $R^{2}$ & 0.381 & 0.381 & 0.370 & 0.534 & 0.533 & 0.515 \\
\hline \# of Obs. & 163 & 163 & 163 & 163 & 163 & 163 \\
\hline
\end{tabular}

$*, * *$, and $* * *$ indicate significance level of $10 \%, 5 \%$, and $1 \%$ respectively. 
Figure 1

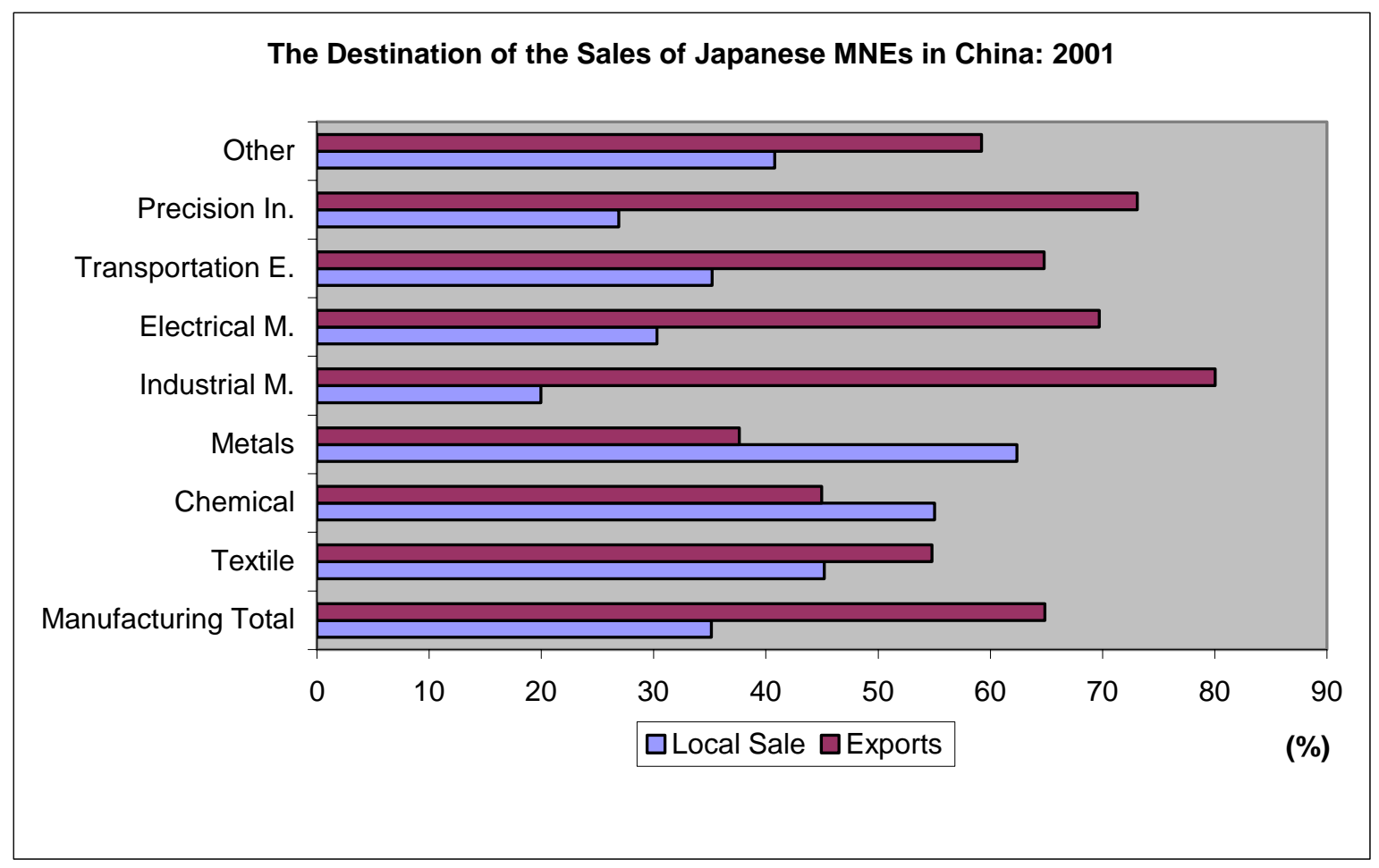

Source: Calculated by the author based on the data in various issues of Quarterly Survey of Business Activities (2002), METI.

Figure 2

The Correlation between Japanese FDI in China and the Real Exchange Rate

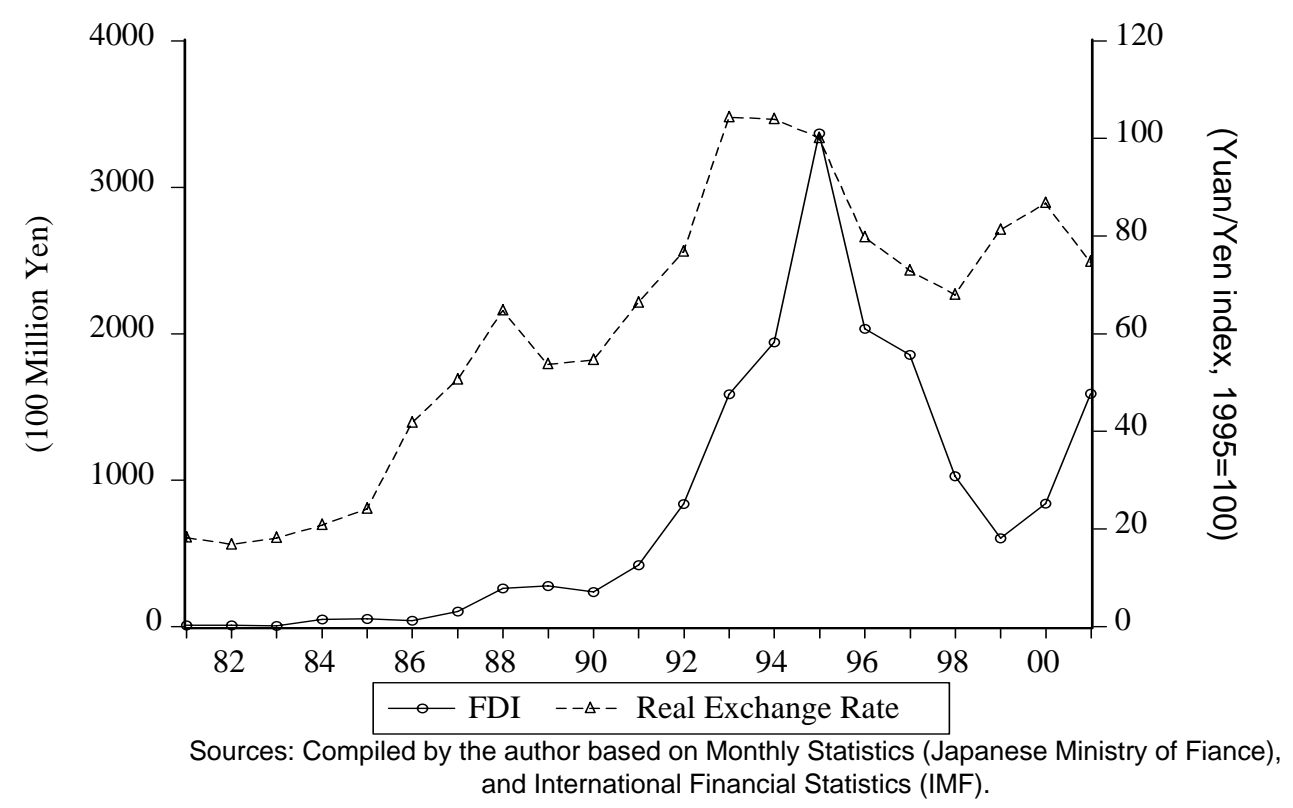


Figure 3

The Relative Wage between Japanese and Chinese Workers

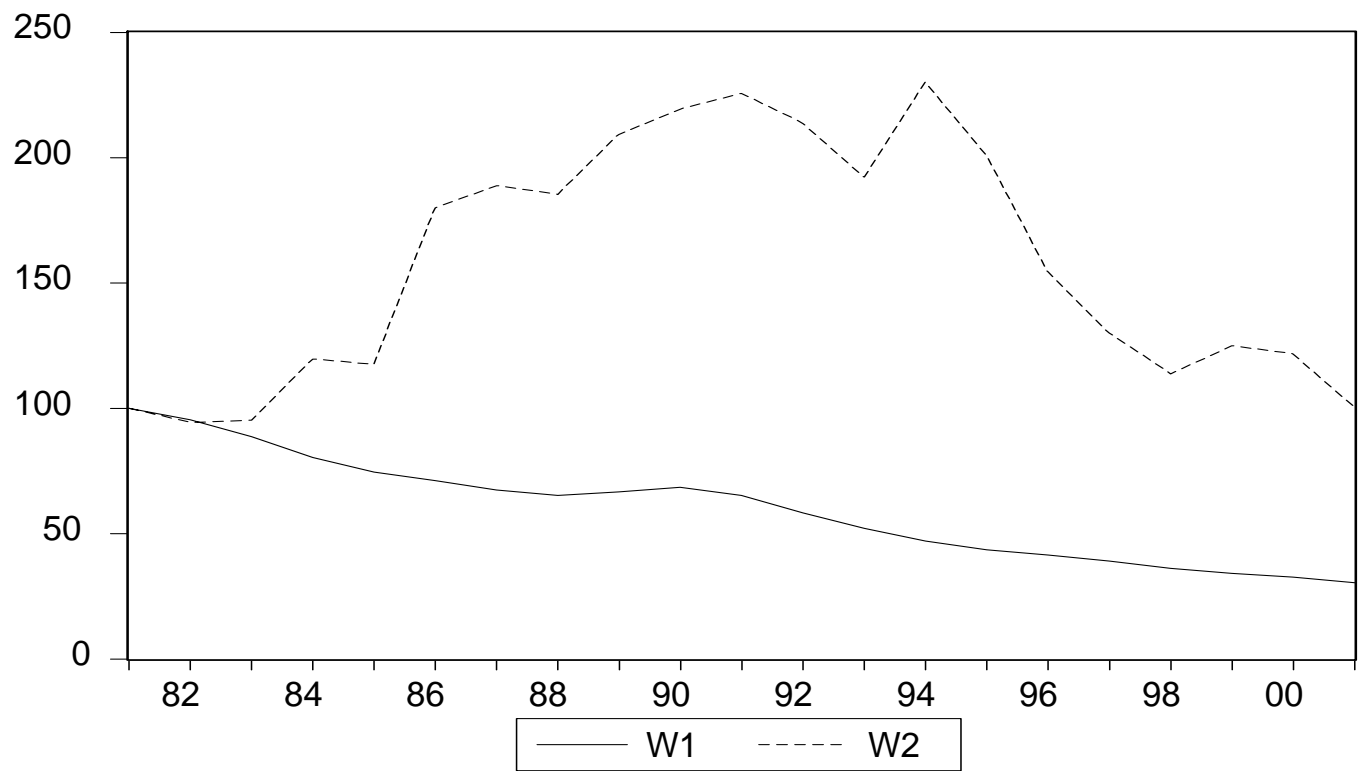

W1: the exchange-rate-free relative wage index W2: the exchange-rate-adjusted relative wage index Both indexes are 100 in 1981

Figure 4

Japanese FDI in China as the percentage of its Total FDI in Asia and the Exchange Rate

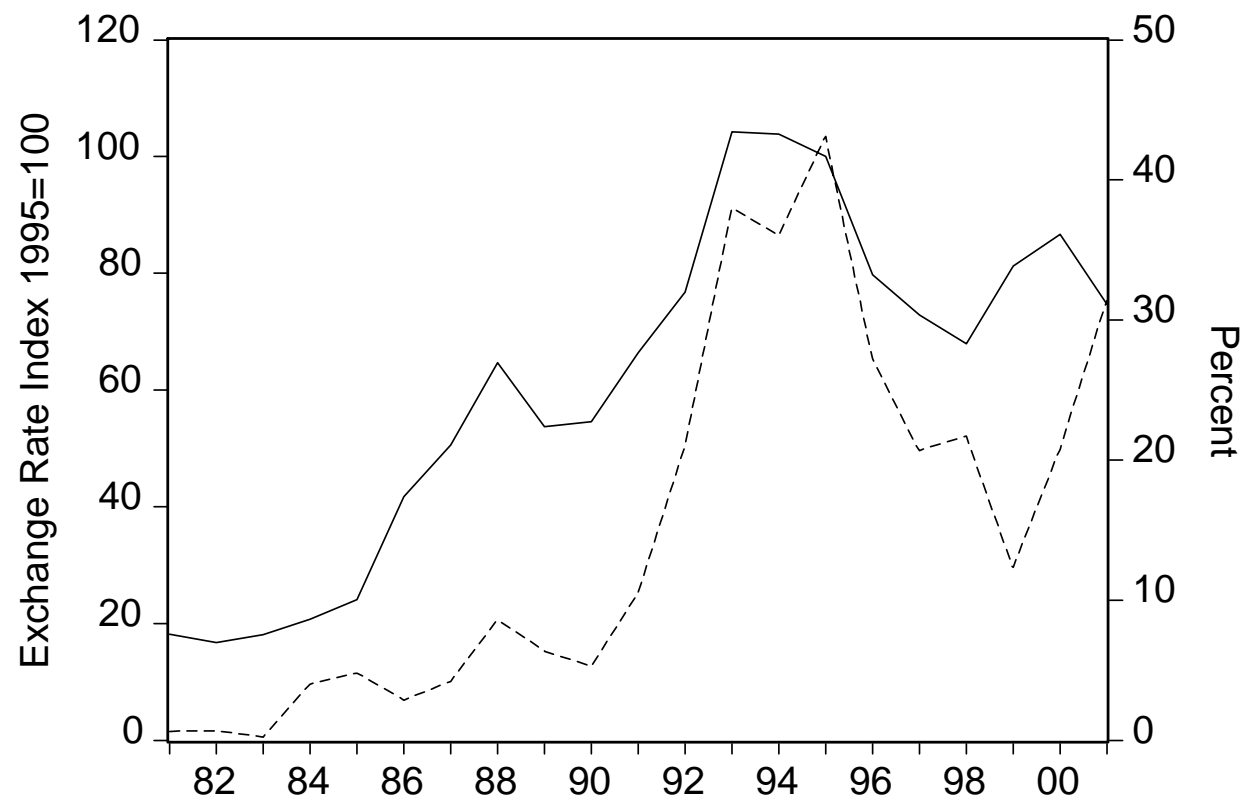

Real Exchange Rate ---- FDI in China 